\title{
ASSESSMENT OF URBAN ECOSYSTEMS: A STRUCTURED APPROACH TOWARDS BUILDING RESILIENCE TO CLIMATE CHANGE IN INDIAN TOWNS AND CITIES
}

\author{
Roy S, Pujari D and Saraswat M \\ Planning and Building, Aga Khan Agency for Habitat, India
}

\begin{abstract}
The fast-urbanizing Indian cities are grappling with rising ecological challenges. Pollution, water insecurity, urban heat, and flooding have increased the vulnerability of the urban population. There is a need to look at urban settlements as a functioning natural ecosystem delineated by administrative boundaries and to evaluate their health regularly through a comprehensive, easy to adopt, structured approach. This study aims to track and evaluate the ecosystem health of three different categories of urban settlements: a group of metropolitan wards, a growing peripheral city, and an emerging town, through adaption of Pressure- State-Response (PSR) framework developed by the Organisation for Economic Co-operation and Development (OECD)'. The methodology includes indices-driven change detection of ecosystem components and pressure points on the same, by using spatial and non-spatial data, developing an impact matrix, and prioritized eco plans for action. Increasing built-up surfaces in the peripheral city $(11 \%)$ and the metropolitan wards (23\%) show increased pressure on their ecosystem in the form of reducing pervious surfaces. Increasing water turbidity, land surface temperatures, and aerosol content in the air depict pressure hotspots requiring mitigative, restorative, and preventive action. A significant decrease observed in heavy vegetation in the metropolitan wards (58\% in the last 5 years) and an increase in industrial activities and aerosol is observed in conjunction with increasing air temperatures and this points towards an impending change in its livability index due to anthropogenic pressures and climate change. The study concludes that a structured approach can aid in agile and sustainable management of our towns and cities and nature-based solutions provide an opportunity to restore the ecosystem balance.
\end{abstract}

Keywords: Urban Assessment Nature-based solutions, Ecosystem Health, Urban Ecosystem, Urban management

\section{Introduction}

The trend of urbanization in India has been very alarming. In 2001, the population residing in urban areas was 28.53\% which rose to 34\% in 2019 (World Bank, 2019). By 2030, more than $40 \%$ of India's population is expected to be urban. Globally, India will be leading the urban population charts along with China, Indonesia, Nigeria, and the USA by 2050. With the rise in Urbanization in India, is impacts that are felt on the urban ecosystems cannot be ignored. For the Census of India 2011 (Census, 2011), the definition of an urban area is a place having a minimum population of 5,000 of density 400 persons per sq. $\mathrm{km}(1,000 / \mathrm{sq}$. mi) or higher, and $75 \%$ plus of the male working population 
employed in non-agricultural activities. Places administered by a municipal corporation, cantonment board, or notified town area committee are automatically considered urban areas. It also defines

Urban Agglomerates as areas of continuous urban spread constituting a town and its adjoining outgrowths (OGs), or two or more physically contiguous towns together with or without outgrowths of such towns. An Urban Agglomeration must consist of at least a statutory town and its total population (i.e., all the constituents put together) should not be less than 20,000 as per the 2001 Census. Similar other combinations in varying local conditions have been treated as urban agglomerations satisfying the basic condition of contiguity - examples: Greater Mumbai UA, Delhi UA, etc. The complexities in the continuum of settlement development, the transition from rural to census town to cities, and some as a part of an agglomeration, are further compounded by differing administrative matrix, planning processes, and management systems. The policies, governance, and fund devolution matrix ranging from local, metropolitan, regional, state to central level further add to the complexities in urban management. Migration, exponential population growth, finite resources, changing climatic conditions, existing and emerging hazards necessitate real-time, preventive, mitigative, and restorative response.

The interface between the ecosystems and the urban areas has not been so harmonious in India. Due to high population density, the challenges related to land degradation, pollution, deforestation are accelerated. Natural ecosystems tend to lose their vigour and natural capacity to deliver the intended ecosystem services. Therefore, one must look at cities as an ecological space that is teeming with natural resources, living and non-living components of ecosystems, and their intrinsic contribution towards human well-being and resilience. Wetlands on the seashore can protect from storm surges and filtration services, while green spaces provide a plethora of ecosystem services (ES). Moreover, the interconnectedness of the urban ecosystem services makes taking corrective action even more complicated. It warrants the development of agile evaluation and correction frameworks for eliminating and minimizing environmental concerns. As the impacts of the environmental issues of urban areas go beyond the administrative boundaries of the urban areas, the analysis and interventions aimed at urban sustainability too need to extend beyond the geographical spaces occupied by the urban areas (Rees, 1996).

Uncontrolled and scattered development of the urban area which causes various problems like traffic congestion, depletes local resources, the problem of amenities, and destroys open spaces is normally considered as an urban sprawl (Johnson, 2001). Alterations in land use are resulting from anthropogenic and natural forces including urban sprawl are a cause of concern (RAM, 1993). Various ecological issues have been arising from the urban sprawl, so it is important to have in-depth insight into this mechanism of urban sprawling for better and effecting utilization of available resources (Hualou Long, 2008). (Bolund, 1999) produced the first identification of the Urban Ecosystem who discussed the ES of seven specific urban ecosystems, namely treed sidewalks, lawns and parks, urban forests, cultivated land, wetlands, lakes and oceans, and streams. Niemela et. al. listed several ES provided by green and water areas in urban regions and classified them as provisioning, regulating, and cultural services. Interestingly, their categorization of regulating services is rather exhaustive as it includes aspects such as regulation of microclimates, gas cycles, carbon sequestration and storage, habitat provision, air pollution purification, noise cushioning, rainwater 
absorption, water infiltration and pollination (Jari Niemelä, 2010). The role of urban ecosystems as natural and nature-based solutions to urban disaster risk reduction has been widely recognized. The coastal mangroves and the pathways to human well-being have been well-documented (Sutton-Grier, 2019)

Global perspectives: Summarizing the impacts of urbanization globally, it is argued that the cities impact ecosystems in 5 different ways (Robert I. McDonald, 2013).

Urban areas are expanding at a faster pace than that the urban population. They require more space, and the ones are witnessing a decrease in population will present different sets of challenges and opportunities than envisioned earlier. Urban areas alter the regional and local weather in myriads of ways- Urban heat island, altered thermal functionality of inland water ecosystems. are some examples. Expanded urban areas extract a significant number of natural resources, agricultural lands, water, energy, etc., as they continue expanding.

Most often, the areas adjacent to the urban centres are the ones that bear the brunt of the expansion of the urban areas. But interestingly, the urban centres are now increasingly growing near coastal areas, biodiversity hotspots, and protected areas. Therefore, ensuring a balance between natural systems and urbanization is essential and yet challenging.

Limitations of administrative and institutional capacities constraints the abilities of financial flows essential to ecological restoration. It could then be argued that an appropriate level of 'whole of the government approach is required for sustainably developing urban centres.

Why is urban ecosystem resilience a key? Urban ecosystem resilience indicates the capacity of ecosystems to withstands the pressures exerted by the conditions surrounding them. Particularly in the face of climate change, urban ecosystems will need natural resilience more than ever. In addition to being the fountainheads of power, innovation, and financial transformation, the cities have higher resource consumption nodes. The dependence and relevance of these urban centres and per-urban regions on the ecosystems cannot be underestimated. Various institutions, actors, and varying levels of agency cannot be ignored while dealing with the challenges of urban ecosystems (Nagendra $\mathrm{H}$., 2013). Capacities, agency, and inter-relationship between various government, non-government bodies are critical for urban sustainability. Social customs, norms, and religious practices too play an important role in modifying the conditions of ecosystems.

The urban areas have increasingly become epicentres of multiple hazards and environmental challenges as little or no attention is paid to the sustainable integration of environmental and sustainable issues (K V Raju et al, 2018).

In India, urban governance is undertaken by disaggregating the urban areas depending upon the population size. Matters of civic governance are categorized and decentralized as per the need. To manage the environmental governance challenges, various environmental norms and guidelines are issued by the Central, State, and Urban Local Bodies. Given the complex nature of the environmental issues and the interlinkages of hazards, there is a need for evidence-based recommendations to improve the environmental policies of urban areas. 
Therefore, these aspects should also be factored in a while mainstreaming climate change adaptation and disaster risk reduction into a broader framework of urban resilience needs.

\section{About the research}

Selection of areas for intervention: The research focus was strongly on understanding the environmental challenges across different levels of urbanization. A metropolis was indeed one of the choices. The second level of urbanization was chosen as that of the peri-urban area. As the metropolis areas grow, the pressures exerted are felt significantly by the areas in geographical proximity. The focus was to assess such impacts on the adjoining city. The third choice was a growing urban centre which is in the phase of a transformation. It was important to assess the status of the environmental conditions as this center too would face similar sustainability challenges that the existing fully grown urban areas are facing currently. Hence, the matrix for identifying three areas, a group of wards exhibiting multiple ecosystem phases (water, land, and coastal area), a peri-urban urban centre, and a transforming town was identified and deployed for evaluation. A group of wards intersected by the Oshiwara River within Municipal Corporation of Greater Mumbai, Vasai Virar Municipal Corporation, and Malia Hatina from Junagadh District of Gujarat. The most striking feature in terms of data identification on these cities was the level of disaggregation and availability of decentralized data in these three contexts. It was observed that while most of the data points are available at a ward level for MCGM, data availability for Vasai Virar Municipal Corporation was at the level of Municipal Corporation (the administrative boundary) without any disaggregation at the ward level. In the case of Malia Hatina, the data was available only at the block level, which subsumed the geographical area beyond the town boundary.

While the urban centers in India are growing and so are the challenges posed by the environmental instability and climate change impacts. Collecting and maintaining data points for various environmental issues is critical. Without spatial-temporal data sets, predicting and forecasting environmental challenges would be extremely crucial.

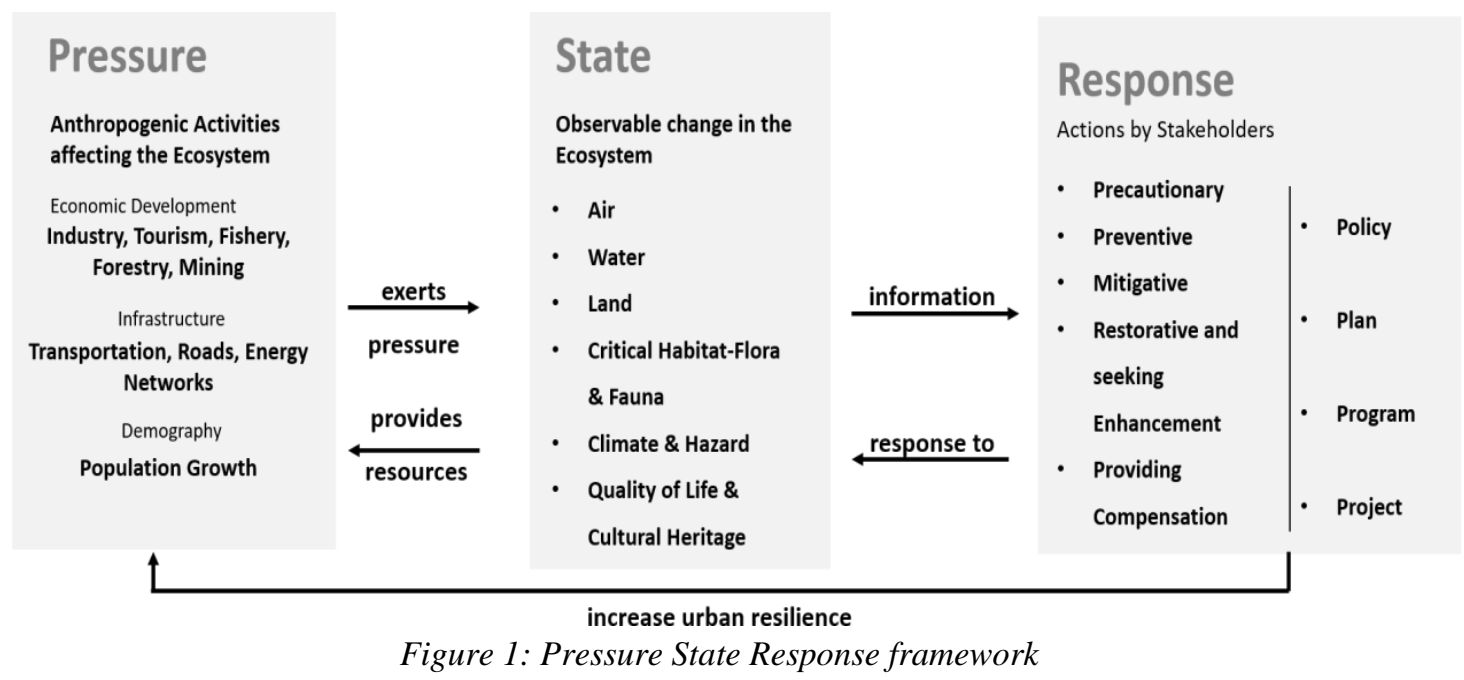

Pressure State Response (PSR) Framework :The PSR framework was developed by the OECD to study ecosystem health (OECD, 2003). The framework is composed of indicators to gauge the impact of anthropogenic activities on the ecosystem. The PSR framework (refer Figure1) highlights links between the pressures of the ecosystem and its impact on the state of the ecosystem to which a response is prepared to identify restorative, mitigative, and preventive solutions to the imbalances in the ecosystem. 


\section{Methodology}

The methodology includes identifying different indicators of the ecosystem, developing an impact matrix, and networks to identify the hotspots for the area. Steps to identify indicators: First, identify the themes that will describe the Pressure/State on an urban ecosystem, divide themes into subthemes. The second is to identify the indicators which describe the Pressure/State on an ecosystem (refer to Table 1).

Table 1. Indicators identified for Water Theme

\begin{tabular}{|l|l|}
\hline Water Theme & Indicators \\
\hline \multirow{5}{*}{ Sub Theme } & Change in Depth of Water Table \\
\cline { 2 - 3 } & Ground Water Extraction Status \\
\hline \multirow{5}{*}{ Groundwater Quality } & Change in Exceedance of Core and General Parameters \\
\cline { 2 - 3 } Surface water Quantity & Exceedance of Trace Metals \\
\cline { 2 - 3 } & Presence or absence of salinity \\
\hline \multirow{5}{*}{ Surface water Quality } & Change in area of Surface Water Quantity \\
\cline { 2 - 3 } & Variation in the number of water bodies \\
\hline & Change in Temperature (in $\left.{ }^{\circ} \mathrm{C}\right)$ \\
\cline { 2 - 3 } & Change in Turbidity of Water \\
\cline { 2 - 3 } & Change in Exceedance of Core and General Parameters \\
\cline { 2 - 3 } & Exceedance of Trace Metals \\
\cline { 2 - 3 } & Exceedance of Parameters-Coastal Water \\
\hline
\end{tabular}

Developing Scoping Impact Matrix and giving Significance: To further assess the impacts on State and its pressures matrices are developed in a form of a grid or table. The pressure indicator having an impact on the state is highlighted in colors depicting a negative or positive impact. After establishing the scoping impact matrix, it is essential to assess and prioritize the most impacted/deteriorating state of the ecosystem. The significance can be given as follows: Significant, major impact - Impacts that are expected to be long term and irreversible. For example, the increase in water-intensive industries will be a critical factor in the increase in groundwater depth. Significant, moderate impact - Impacts are long-term but reversible. Insignificant, minor impact - Impacts are considered to be short-term, reversible, and/or localized in extent. For example, the quantity of surface water won't be impacted by the consumption due to irrigation. 
Table 2. Impact matrix and giving significance

\begin{tabular}{|c|c|c|c|c|c|c|c|c|c|c|c|c|c|}
\hline \multirow{3}{*}{$\begin{array}{l}0 \\
\vdots \\
0 \\
0 \\
\vdots \\
\vdots\end{array}$} & \multirow{3}{*}{\multicolumn{2}{|c|}{ State }} & \multicolumn{2}{|c|}{$\begin{array}{c}\text { Ground Water } \\
\text { Quantity }\end{array}$} & \multirow{2}{*}{\multicolumn{3}{|c|}{\begin{tabular}{|l} 
Ground Water Quality \\
Exceedance in parameter
\end{tabular}}} & \multirow{2}{*}{\multicolumn{3}{|c|}{$\begin{array}{l}\begin{array}{l}\text { Surface Water } \\
\text { Quantity }\end{array} \\
\text { Variation }\end{array}$}} & \multicolumn{3}{|c|}{ Surface Water Quality } \\
\hline & & & \multirow[b]{2}{*}{ Depth } & \multirow[b]{2}{*}{$\begin{array}{l}\text { Extracti } \\
\text { on } \\
\text { Status }\end{array}$} & & & & & & & & Exce & dance \\
\hline & & & & & Core & General & $\begin{array}{l}\text { Trace } \\
\text { Metal }\end{array}$ & area & $\begin{array}{l}\text { water } \\
\text { body }\end{array}$ & Temp & Turbidity & Core & $\begin{array}{c}\text { Genera } \\
1\end{array}$ \\
\hline \multirow{7}{*}{\multicolumn{2}{|c|}{ 氧 }} & Area under agriculture & & & & & & & & & & & \\
\hline & & Cropping Pattern & & & & & & & & & & & \\
\hline & & Agricultural Yield & & & & & & & & & & & \\
\hline & & area under horticulture & & & & & & & & & & & \\
\hline & & Horticultural Yield & & & & & & & & & & & \\
\hline & & Fertilizers \& Pesticides & & & & & & & & & & & \\
\hline & & $\begin{array}{l}\text { Consumption for } \\
\text { irrigation }\end{array}$ & & & & & & & & & & & \\
\hline 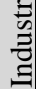 & 匇 & water polluting industries & & & & & & & & & & & \\
\hline
\end{tabular}

Advanced impact network : Network diagrams help identify the impact between the cause (Pressure) and the receptor (State). These thus provide the mechanism for linking first and higherorder impacts. It can assess multiple impacts at the same time and helps in identifying upcoming or existing hazards within the ecosystem. The impact can also be given significance to help in prioritizing and identifying the concerned stakeholders. For example, an increase in water consumption (Pressure) can lead to impacts on water quantity and quality (State), and that in turn can lead to health impacts (State).

Tools for assessment : To assess the state of the ecosystem spatial tools (Satellite imageries) and non-spatial tools (time series data) were used (refer to Table 3). Time-series data were analysed to understand the short- and long-term effects of hazards and climate change.

Table 3: Spatial and Non-Spatial tools used for Assessment

\begin{tabular}{|l|l|}
\hline Tool used & Data \\
\hline Remote Sensing (2015-2019) & Normalized Difference Water Index (NDWI) \\
\cline { 2 - 3 } & Normalized Difference Vegetation Index (NDVI) \\
\cline { 2 - 2 } & Normalized Difference Turbidity Index (NDTI) \\
\cline { 2 - 2 } & Normalized Difference Built Index (NDBI) \\
\cline { 2 - 2 } & The extent of Impervious Surfaces through Land Use Land Cover \\
\cline { 2 - 2 } & Sea Surface Temperature Index \\
\cline { 2 - 3 } & Land Surface Temperature \\
\cline { 2 - 3 } & Seasonal Variability of Aerosol Optical Depth \\
\hline Image Processing & The extent of Mangrove Forest \\
\hline Long Term Analysis - Mann & $\begin{array}{l}\text { Climate Variables, Ground Water Depth, Exceedance in water } \\
\text { parameters }\end{array}$ \\
\hline
\end{tabular}




\begin{tabular}{|l|l|}
\hline $\begin{array}{l}\text { Short term Analysis (over a period of } 3 \\
\text { years) }\end{array}$ & $\begin{array}{l}\text { Concentration in Ambient Air quality, Exceedance in water } \\
\text { parameters }\end{array}$ \\
\cline { 2 - 2 } & Violation Analysis \\
\hline
\end{tabular}

\section{Hotspot Identification:}

Metropolitan Ward- Oshiwara : Oshiwara region falls under the Mumbai Metropolitan Region (MMR. The study area consisted of 6 wards with a population of 4.0 million. Oshiwara is rich in its ecological fabric, with proximity to Thane creek on its left and Sanjay Gandhi National Park (SGNP) to its north, and lakes. Oshiwara faces high demand for construction activities within $11 \mathrm{~km}$ of proximity to the biodiversity hotspots (refer to Figure 2). Some significant patterns were observed due to urbanization in the study area. On further analysis of each state component, some key hotspots were identified: Vegetation near the SGNP has deteriorated primarily due to a boom in construction activities. A significant decrease in heavy vegetation of the SGNP in the last five years due to human settlement encroachments (refer to Figure 3) which factors to direct threat to the existing mammal species in the SNGP. With the increase in urbanization the surface water quality has also degraded due to sewer disposal, industry effluents.

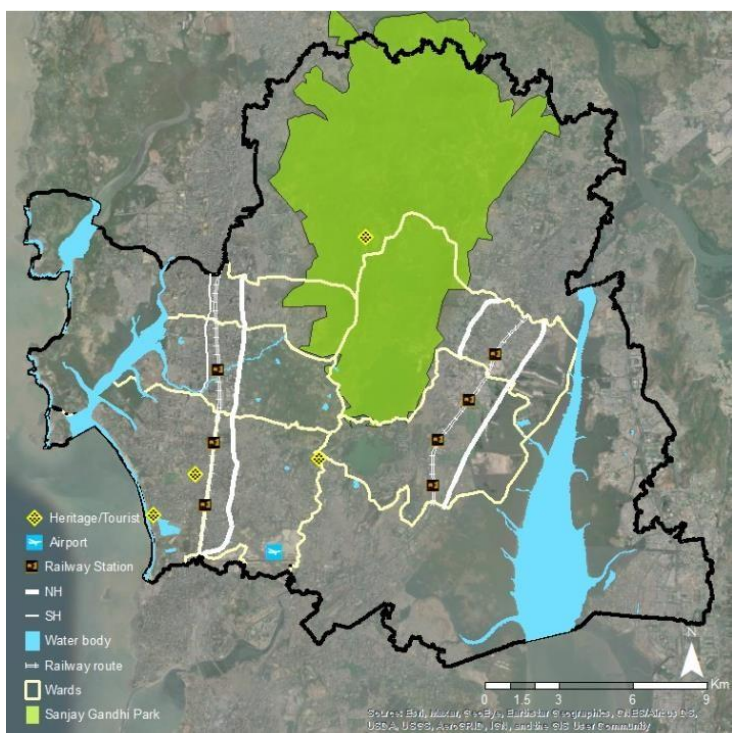

Figure 2. Location of Oshiwara 


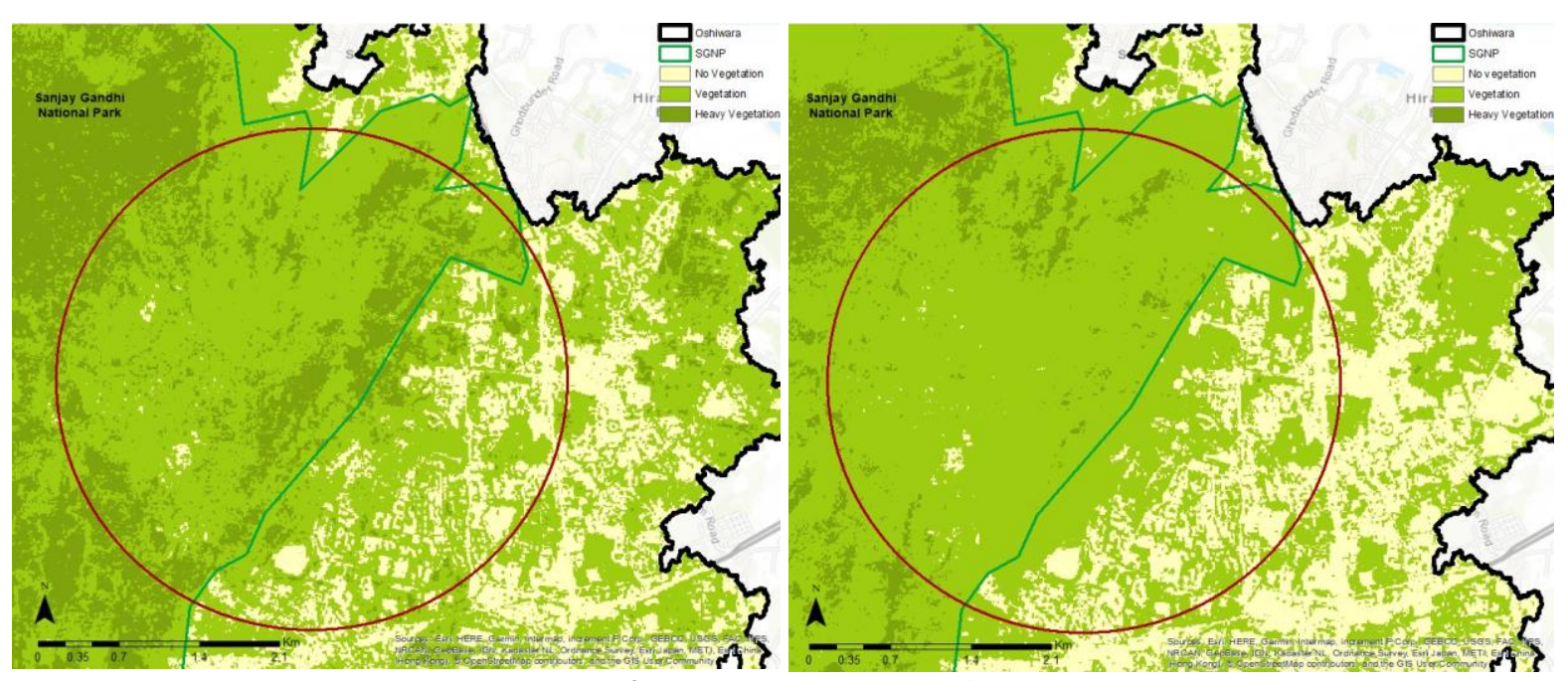

Figure 3. Loss in vegetation in SGNP
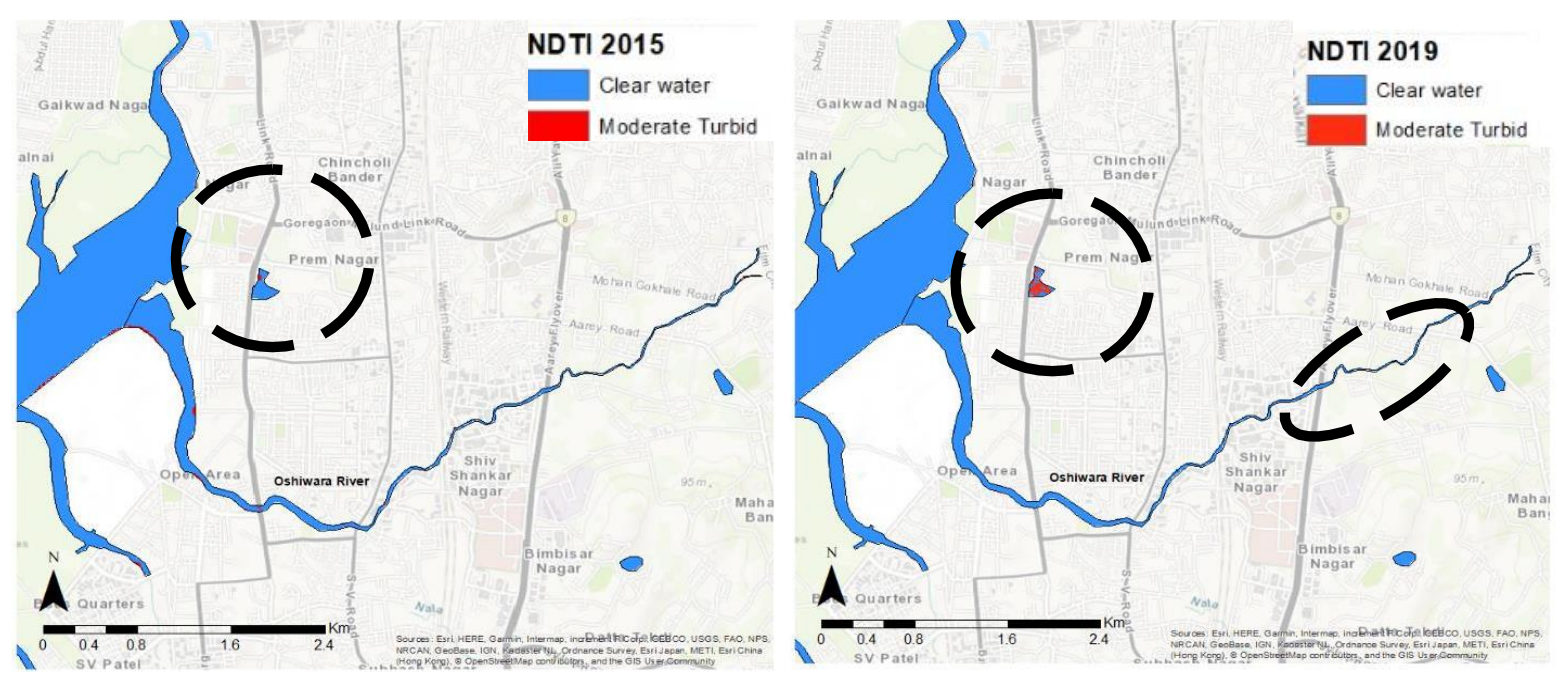

Figure 4. Increase in moderate turbid water along the Oshiwara River
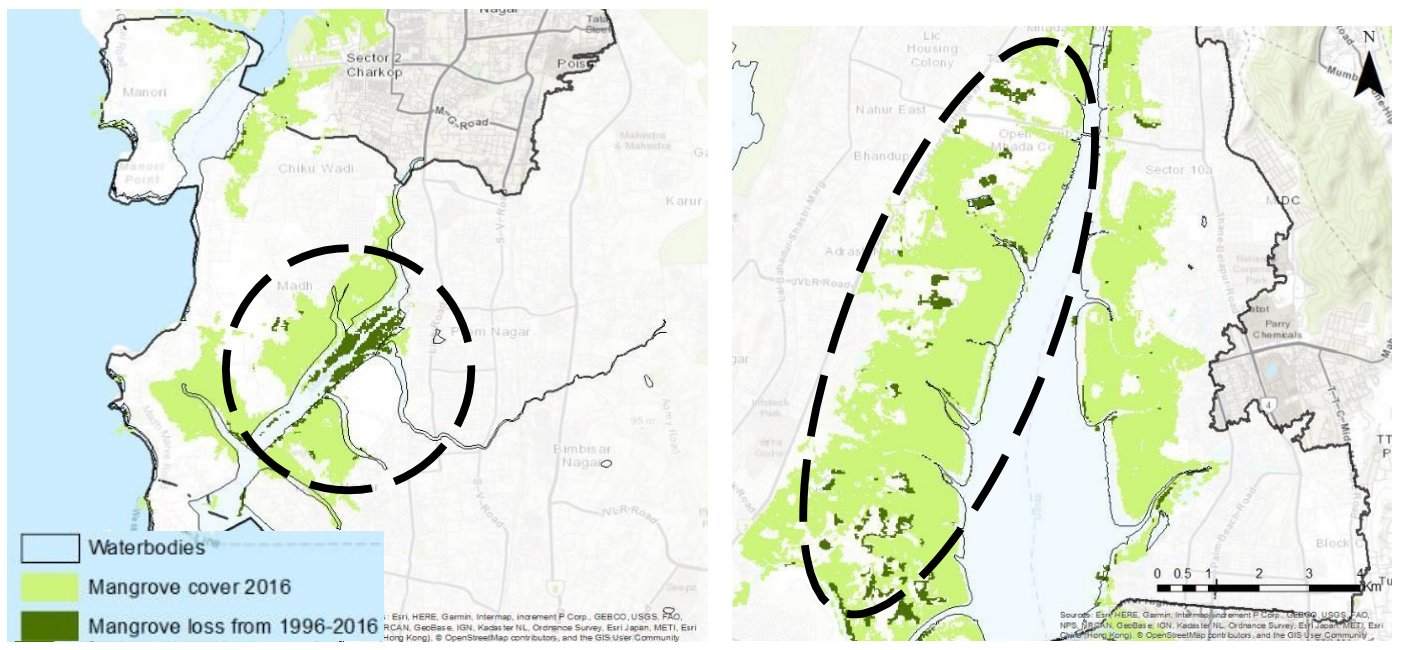

Figure 5: Changes in Mangrove abundance (1996\&2016) in Oshiwara river system (left) and Thane Creek (right) 
Peri Urban City- Vasai Virar: Vasai Virar is administered by Vasai Virar Municipal Corporation (VVMC) and is part of the Greater Mumbai region. To the west is the Arabian sea; east is the Tungareshwar hills; south is the Vasai Creek and Vaitarna river to its north (refer to Figure 6). Being a peri-urban area, it has faced a large influx of population from adjoining areas to have access to affordable housing and jobs which has severely impacted the ecosystem. It is rich in its biodiversity as the presence of wetlands, creek, salt pans, forests, agriculture zone, etc. The total vegetation in Vasai Virar has shown a reduction of $8 \%$ in its area which is a threat to the threatened flora and fauna species present. The presence of railways and expressways near Vasai creek has paved its way for development in the natural terrain, attributing to the loss of mangroves along the creek (refer to Figure 7). Pelhar Dam in Tungeshwar Forest is sourced by the Pelhar river which provides 10 MLD of water for the city. It is also one of the hotspots facing imbalances due to increased anthropogenic activities. On analyzing the Built index near the dam, it has shown a significant increase in built-up area around it (refer to Figure 8). This development has led to an increase in sewage disposal in the river resulting in an increase in turbid water along the lake. The deteriorating water quality will be a threat to the health of the people, fauna species depending on the lake. With the increase in a built-up area by $11 \%$ from $2015-19,28 \%$ of the area under industries, slums, and forest show an increase in land surface temperature from $2 \%$ in summer months whereas, the areas near the creek, lakes, and salt pans have shown a $2 \%$ decrease in temperature from 2009-19. The variation in the temperatures for the summer months of 2019 can be seen in the LST map (refer to Figure 9).

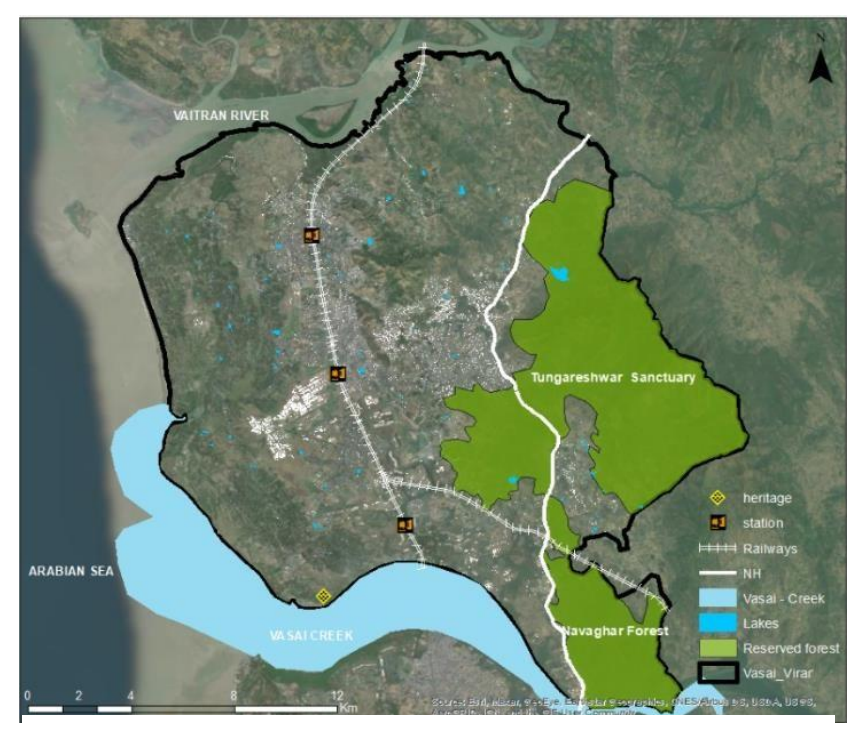

Figure 6. Location of Vasai Municipal Corporation Area 


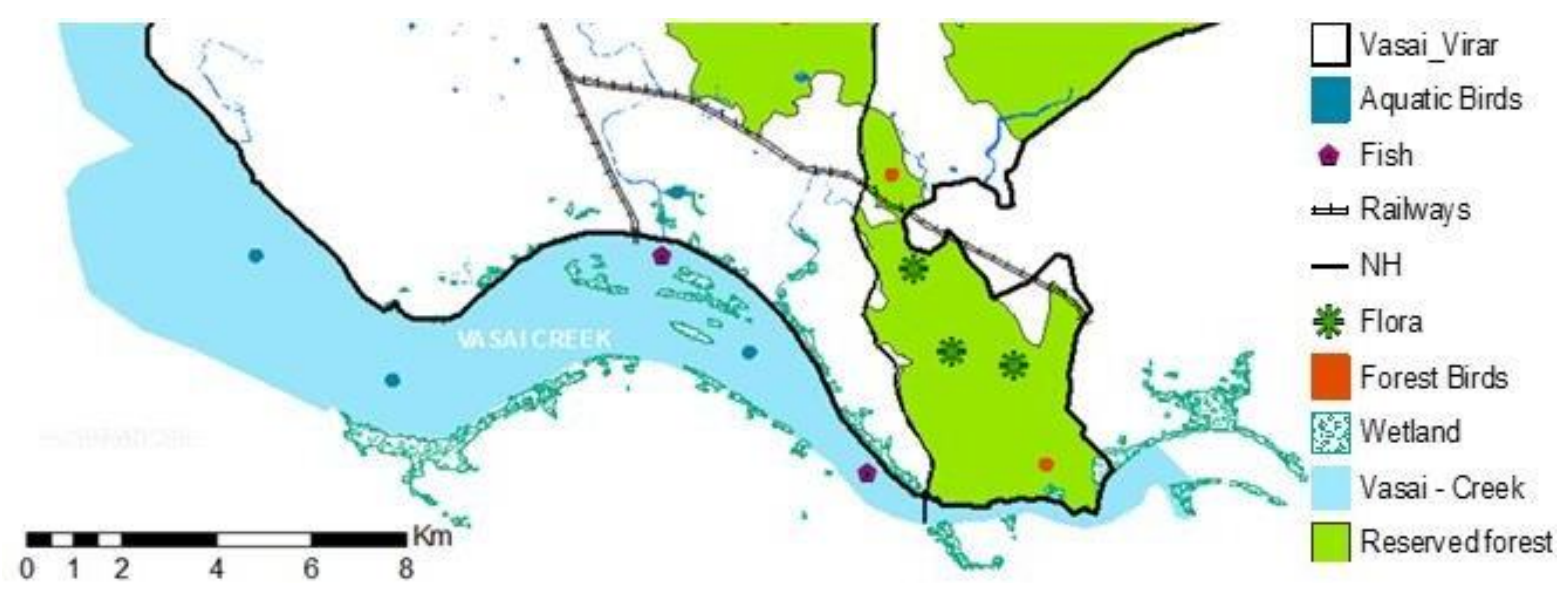

Figure 7. Loss of mangrove along the Vasai Creek

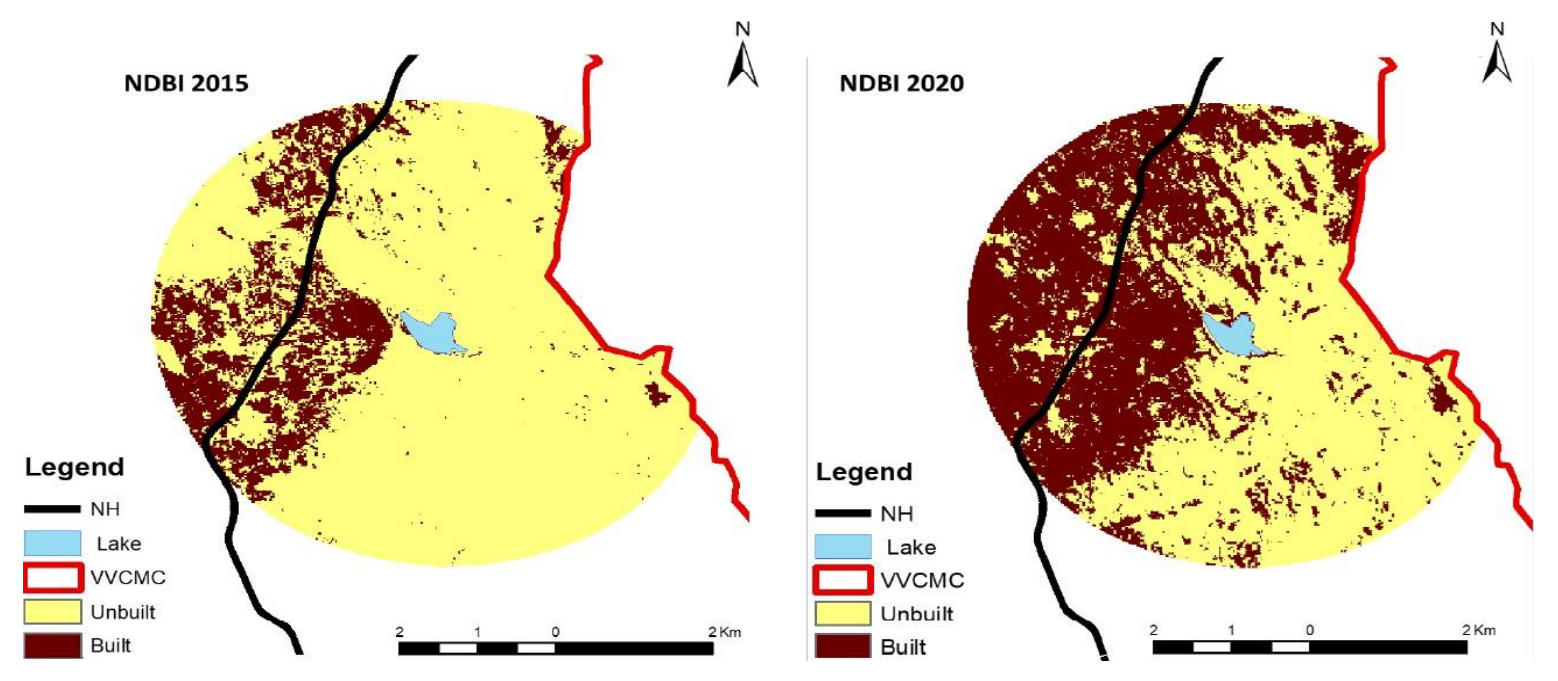

Figure 8. Change in Built up area around the Pelhar Dam from 2015-2019 


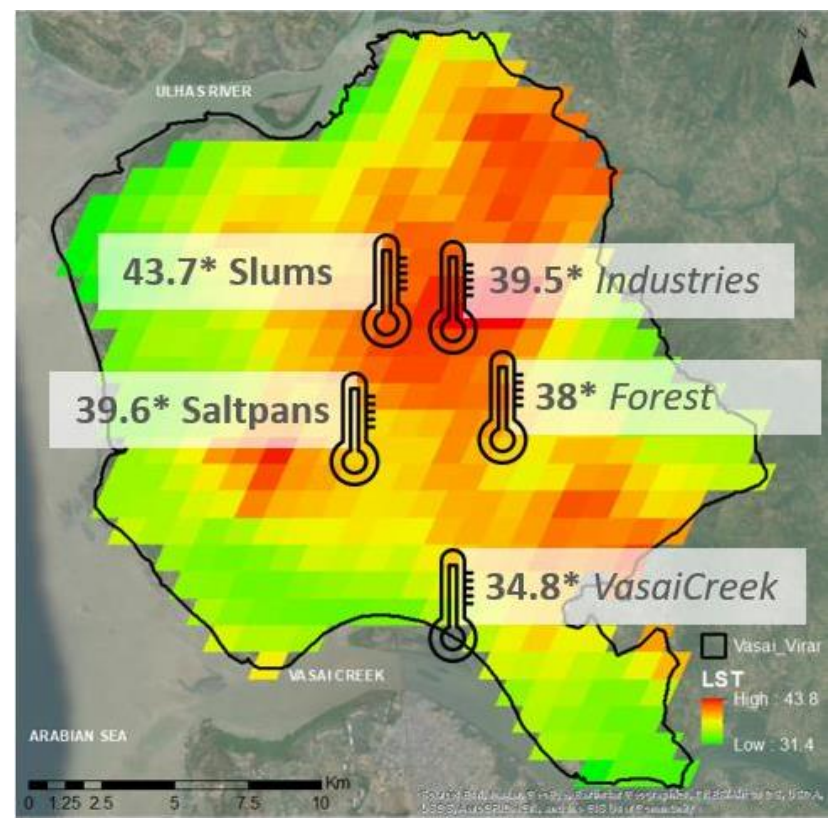

Figure 9. Land Surface temperature for summer months of 2019-Vasai Virar

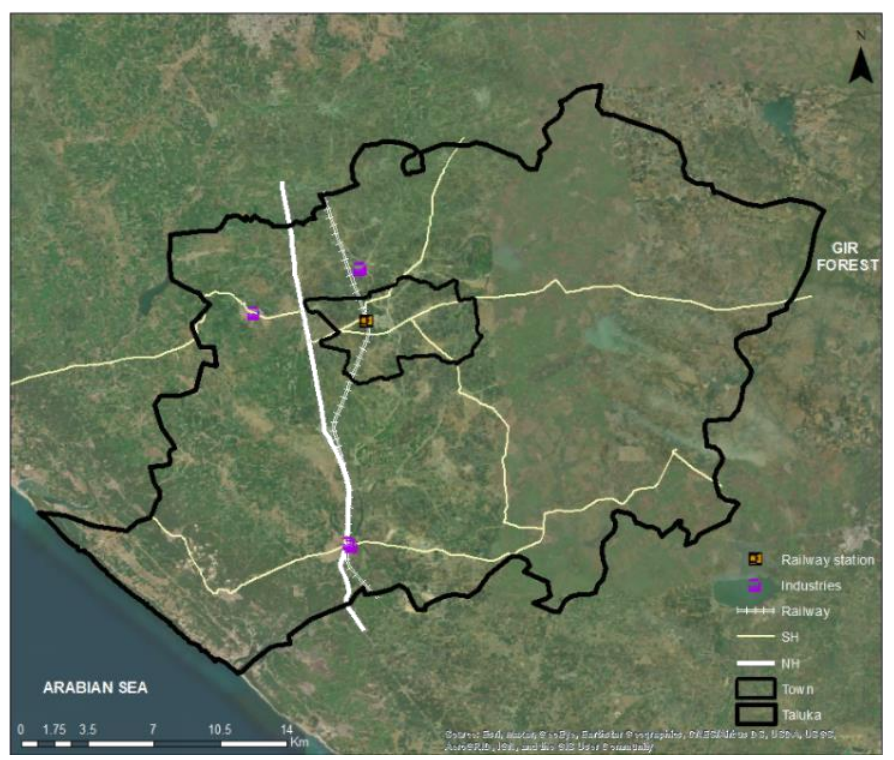

Figure 10. Location of Malia Hatina 
Malia Hatina- A transforming town: Malia Hatina is a primarily agrarian town located in the Junagadh district, Malia Taluka of Gujarat. It is in proximity to the Gir Wildlife Sanctuary (refer to Figure 10). Meghal River flows through the heart of the town and is a vital source of water to the region. Agriculture is the primary occupation of the town, is more prone to water-related challenges. To further understand the status of water, ground data was analysed from five observation wells located within the Taluka. The long-term trends in Total Hardness and Depth of Water Table (refer to Table 4) were conducted by using Mann-Kendall's Trend Test. For Total Hardness, it was observed that $50 \%$ of the observation wells show improvement in water quality in both long-term trends and short term, but more than $50 \%$ of the samples showed violations. This indicates that the three wells are Minor Hotspots and need intervention to continue improvement in water quality. Moraj and Prempara also indicate deterioration in the short term, as well as violations exceeding $50 \%$. These wells can be classified as Major, Hotspots. The quality of surface water along the Meghal river has also deteriorated due to an increase in water-polluting industries and untreated agricultural run-offs in the area which has led to an increase in the turbidity of the surface water from 2016-2020(refer to Figure 11). This becomes a critical hotspot as it may cause a serious threat to people's health depending on the river.

Table 4. Long Term Analysis of Hardness in Ground water(Left), Long term analysis on the ground water depth (Right)

\begin{tabular}{|l|l|l|l|l|}
\hline $\begin{array}{l}\text { Observ } \\
\text { ation } \\
\text { wells }\end{array}$ & $\begin{array}{l}\text { Long term } \\
\text { Trend } \\
\text { Analysis }\end{array}$ & $\begin{array}{l}\text { Short } \\
\text { term } \\
\text { Trend } \\
\text { Analysis }\end{array}$ & $\begin{array}{l}\text { Violatio } \\
\text { n (more } \\
\text { than 200 } \\
\text { mg as as } \\
\text { per IS } \\
10500)\end{array}$ & Inference \\
\hline Well-1 & $\begin{array}{l}\text { Significant } \\
\text { Decrease }\end{array}$ & $\begin{array}{l}\text { No } \\
\text { Change }\end{array}$ & $87 \%$ & $\begin{array}{l}\text { Minor } \\
\text { Hotspot }\end{array}$ \\
\hline Well-2 & $\begin{array}{l}\text { Significant } \\
\text { Decrease }\end{array}$ & $\begin{array}{l}8 \% \\
\text { Decrease }\end{array}$ & $100 \%$ & $\begin{array}{l}\text { Minor } \\
\text { Hotspot }\end{array}$ \\
\hline Well-3 & $\begin{array}{l}\text { Significant } \\
\text { Decrease }\end{array}$ & $\begin{array}{l}8 \% \\
\text { Increase }\end{array}$ & $71 \%$ & $\begin{array}{l}\text { Major } \\
\text { Hotspot }\end{array}$ \\
\hline Well-4 & $\begin{array}{l}\text { Significant } \\
\text { Decrease }\end{array}$ & $\begin{array}{l}25 \% \\
\text { Increase }\end{array}$ & $100 \%$ & $\begin{array}{l}\text { Major } \\
\text { Hotspot }\end{array}$ \\
\hline Well-5 & $\begin{array}{l}\text { Significant } \\
\text { Decrease }\end{array}$ & $\begin{array}{l}45 \% \\
\text { Decrease }\end{array}$ & $87.5 \%$ & $\begin{array}{l}\text { Minor } \\
\text { Hotspot }\end{array}$ \\
\hline
\end{tabular}

\begin{tabular}{|l|l|l|l|}
\hline $\begin{array}{l}\text { Observa } \\
\text { tion } \\
\text { wells }\end{array}$ & $\begin{array}{l}\text { Long term } \\
\text { Trend } \\
\text { Analysis }\end{array}$ & $\begin{array}{l}\text { Short term } \\
\text { Trend } \\
\text { Analysis }\end{array}$ & Inference \\
\hline Well-1 & Increase & $\begin{array}{l}60 \% \\
\text { decrease }\end{array}$ & $\begin{array}{l}\text { Needs more } \\
\text { frequent } \\
\text { monitoring }\end{array}$ \\
\hline Well-2 & Increase & $\begin{array}{l}70 \% \\
\text { Decrease }\end{array}$ & $\begin{array}{l}\text { Needs more } \\
\text { frequent } \\
\text { monitoring }\end{array}$ \\
\hline Well-3 & Increase & $\begin{array}{l}32 \% \\
\text { Decrease }\end{array}$ & $\begin{array}{l}\text { Needs more } \\
\text { frequent } \\
\text { monitoring }\end{array}$ \\
\hline Well-4 & Increase & $\begin{array}{l}36 \% \\
\text { Decrease }\end{array}$ & $\begin{array}{l}\text { Needs more } \\
\text { frequent } \\
\text { monitoring }\end{array}$ \\
\hline Well-5 & Increase & $\begin{array}{l}28 \% \\
\text { Decrease } \\
\text { frequent } \\
\text { monitoring }\end{array}$ \\
\hline
\end{tabular}



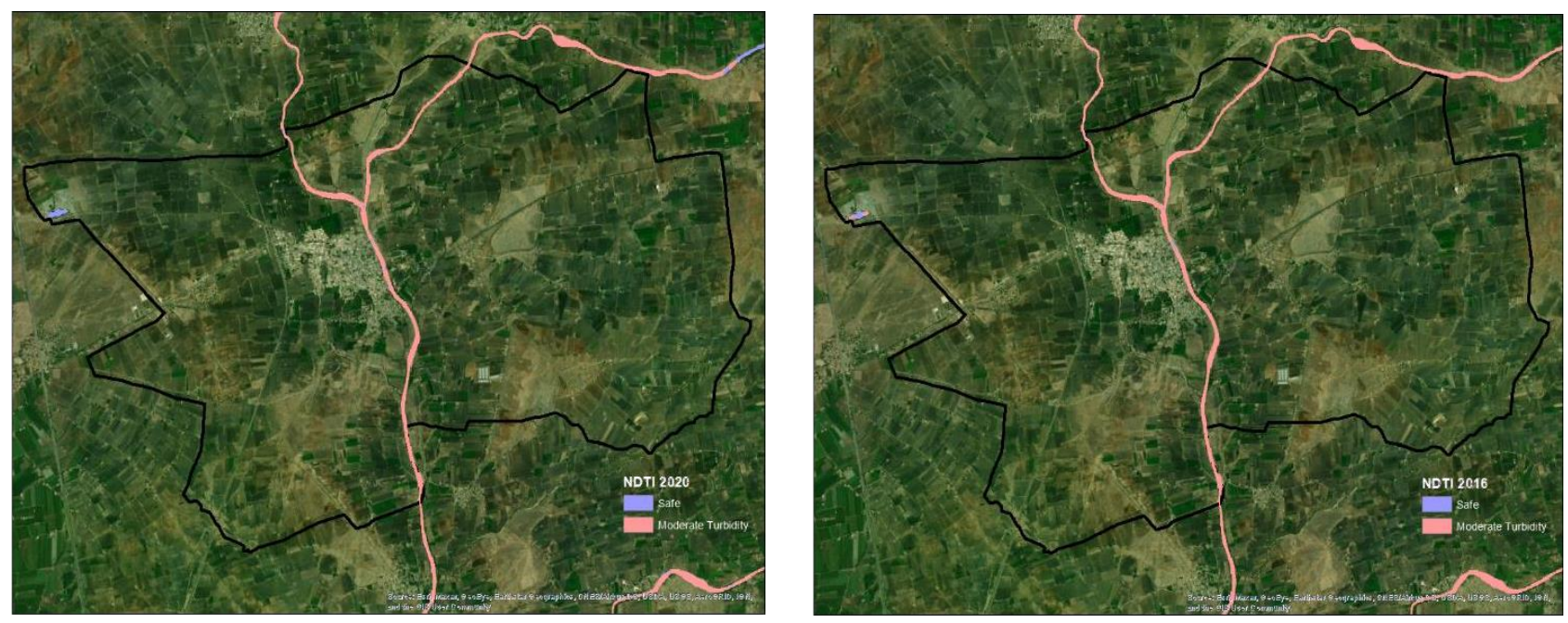

Figure 11. Change in turbid water along patches of Meghal River

\section{Results and Discussion}

The state of the ecosystem of a metropolitan ward - Oshiwara in Mumbai, India:

Land: Increase in built up by $23 \%$ in five years from and reduction in vegetation by $58 \%$ and in wasteland and scrublands which serve as pervious surfaces and buffers by $41 \%$ as established through LULC change detection undertaken through Sentinel 2 satellite imagery data for the year 2015-19 (refer to Figure 12). Mangrove cover has seen a reduction by $9 \%$ in the river delta region and the creek region. Rapid urbanization is often characterized by two prominent features-a boom in construction (increased built-up area) and loss of natural ecosystem habitats (decreased vegetation cover). Silting of river basins and lakes increases the overall flood hazard in settlements as the depth of water bodies gets significantly reduced. 

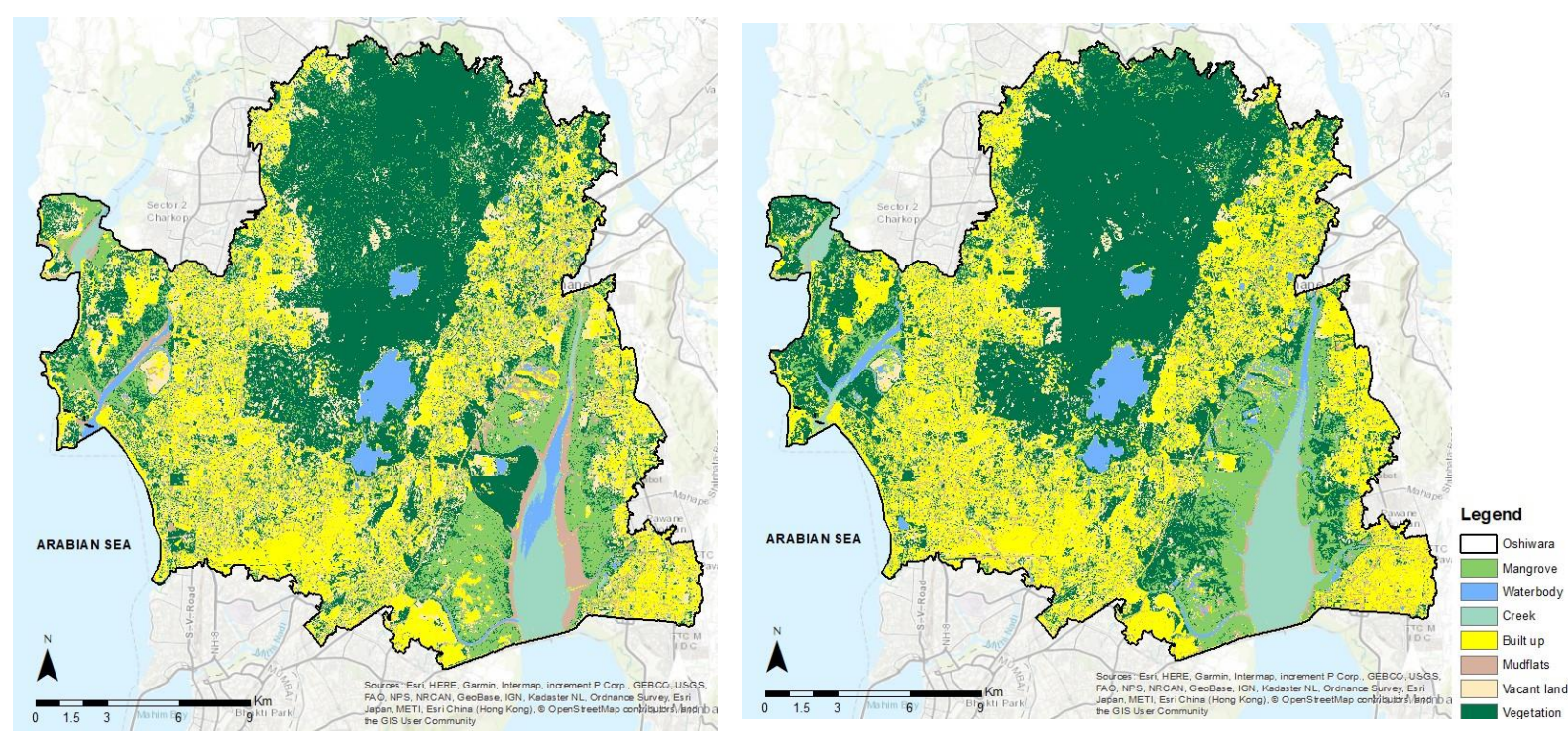

Figure 12. LULC map of Oshiwara 2015 and 2019

Water: The surface water area with an increase in turbidity is $7 \mathrm{sq} . \mathrm{km}$ out of $34 \mathrm{sq} . \mathrm{km}$ of surface water as per the Turbidity Index (NDTI) data procured from Sentinel 2 satellite image. The primary source of such pollutants in water bodies is through drainage discharges, industrial effluents, and biological activity in stagnant water and silting, resulting in a decrease in water depth. For the case under study, discharges in water have increased, or treatment facilities have not kept pace with the increase. Approximately $55 \%$ of the domestic effluent is treated in the case studied. Groundwater hardness and its chloride content show a significant $320 \%$ and $31 \%$ increase as detected from secondary data from (CGWB, India WRIS, 2019) using short-term analysis for the last three years. The groundwater shows a significant decrease in $80 \%$ of the monitored observation wells which establishes that there is an increase in extraction possibly for industrial uses, reduction in recharge due to increase in pervious surfaces, and pollution due to the discharge of untreated effluents and water which infiltrate and contaminate groundwater.

Air: There has been a $2 \%$ increase in maximum temperatures over 30 years (1990-19) which can be influenced due to an increase in built-up area and reduction in vegetation cover the National Park, the coastal land and sea breeze have also influenced the ambient temperature. The Aerosol Optical Depth: $58 \%$ and $91 \%$ of the area shows an increase in summer and post-monsoon, respectively, indicating an increase in air pollution.

The state of the ecosystem in a peri-urban: Vasai Virar Municipal region -Maharashtra: Land: The peri-urban area under study is separated from the metropolis by a creek and exhibits a boom in the population (76\%. growth in 10 years) and an $11 \%$ increase in a built-up area in 5 years from 2015-2019. The change in built-up areas is seen primarily from wasteland and vegetation as seen in the change detection maps (refer to Figure 13 and Figure 14). The increase in the built-up area near the catchment of water bodies with a significant reduction in vegetation area of the water bodies has further been observed through detection of the change in vegetation and built index (refer to Figure 15 and (refer to Figure 16). 

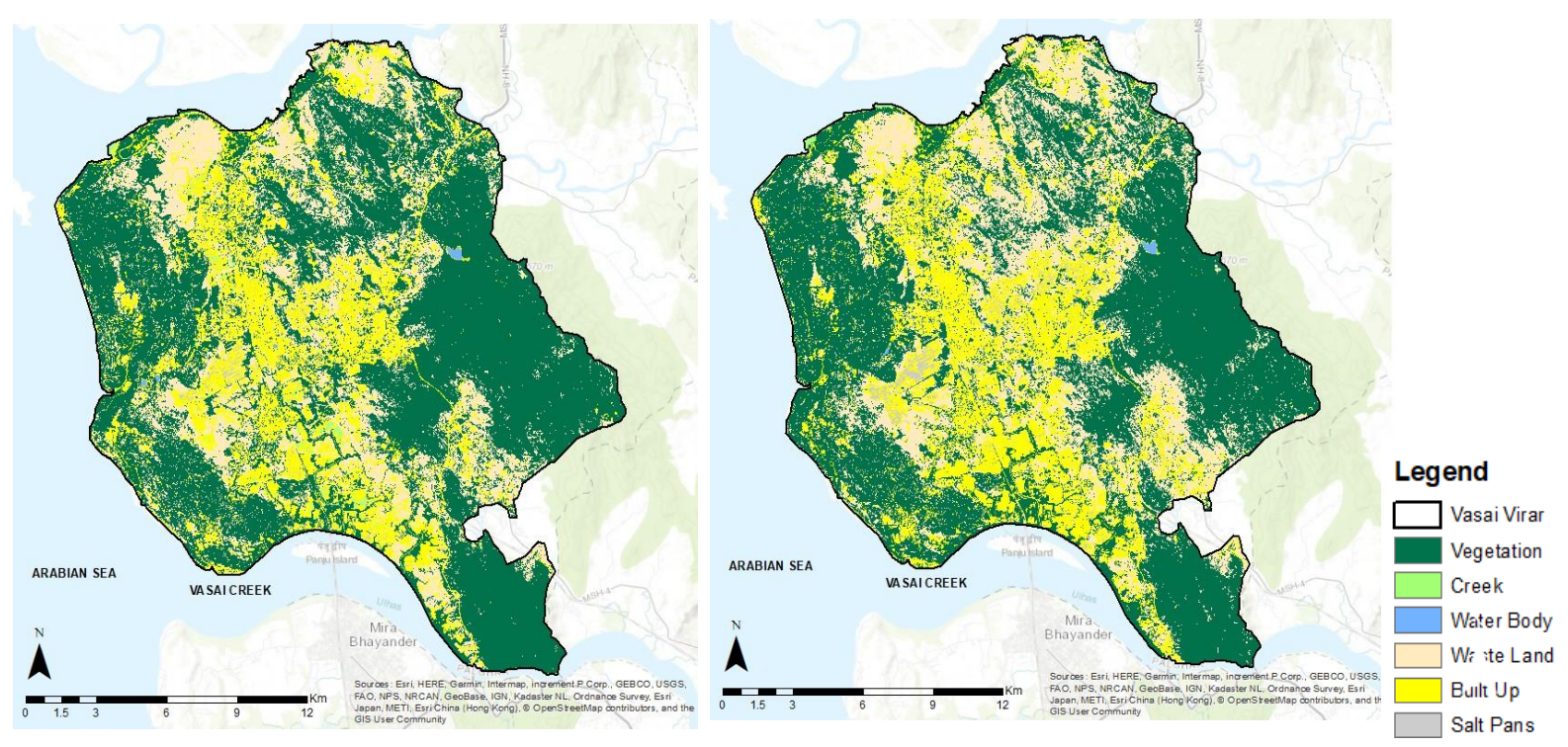

Figure 13. Change in LULC of Vasai virar from 2015-2020

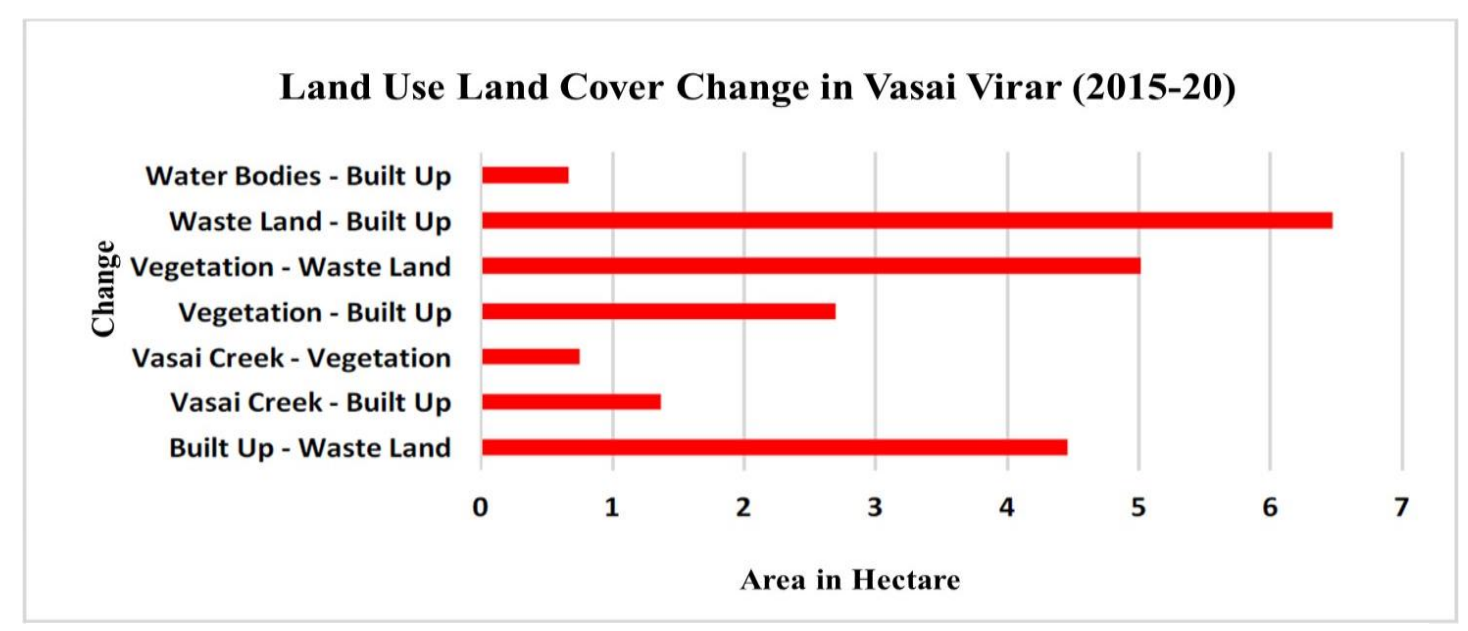

Figure 14. Change detection in LULC in Vasai Virar from 2015-2020 


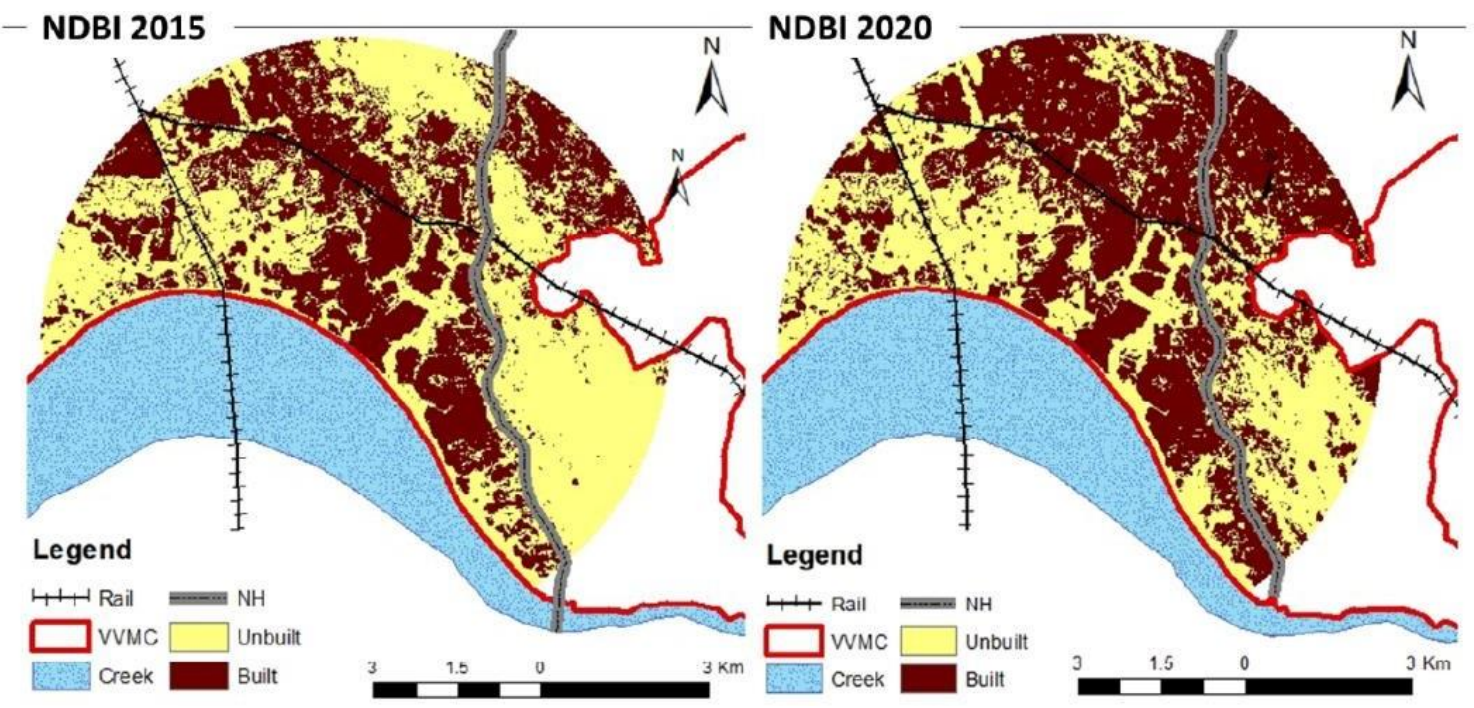

Figure 15. Change in built up along Vasai Creek from 2015-2020

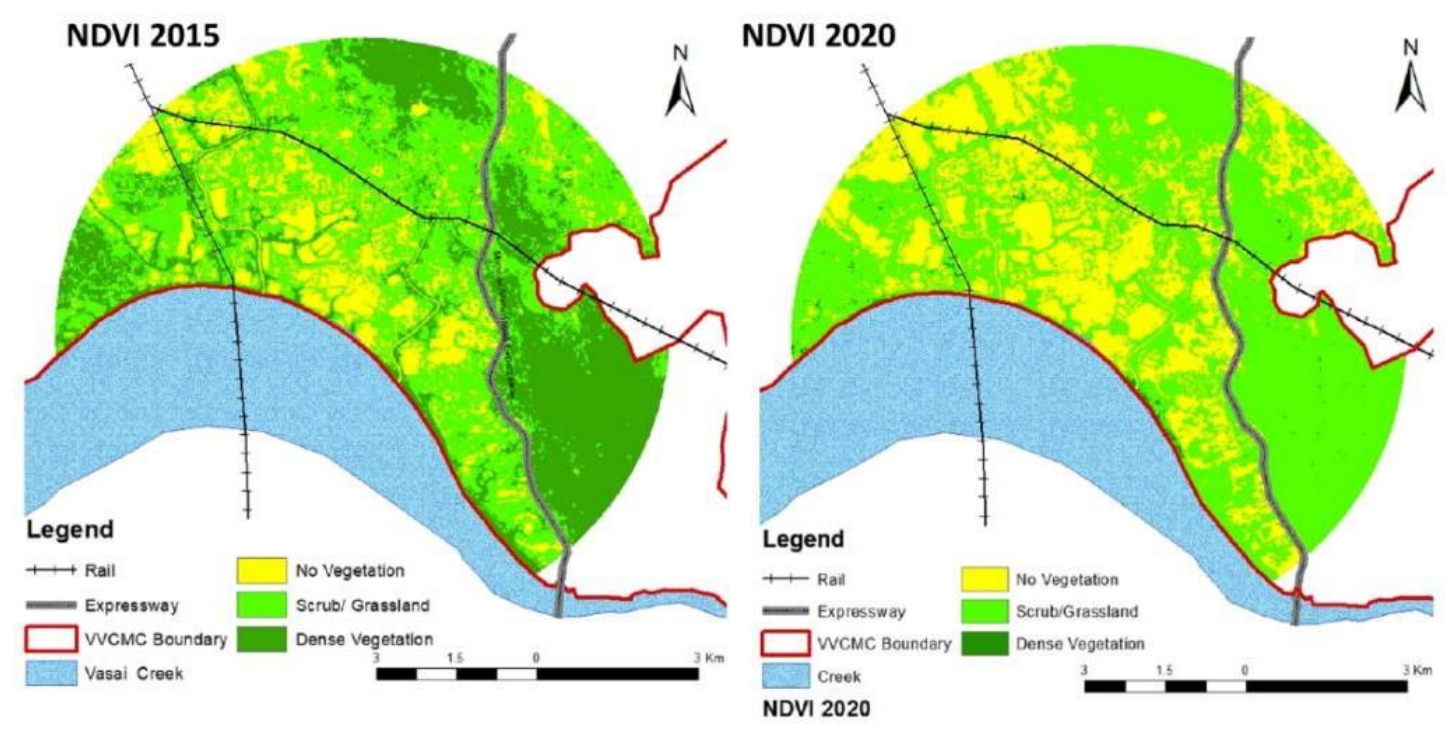

Figure 16. Change in Vegetation along Vasai Creek from 2015-2020

Water: Surface water area has decreased by $30 \%$ over 5 years from $2015-2019$ as found through the water index analysis. Increased violations in total dissolved solids, total fixed solids, and total suspended solids by 90,69 , and $132 \%$ respectively were observed from the analysis (CGWB, India WRIS, 2019). Increasing pollution of water bodies is caused due to discharge of sewerage and effluents and is aggravated due to siltation which is caused due to reduction in buffer spaces and reduction in green cover. About 1/3rd of the total sewerage generated (105MLD) in the municipal area is treated (35MLD) for the Vasai Virar Municipal Corporation as available from secondary sources. The peri-urban city has around $2.7 \%$ of the land under industries, has 12 industrial zones and of the total industries, $86 \%$ are water-polluting industries as listed in the Directorate of Industrial Safety and Health (DISH, 2019). A significant increase in fluorine content by $35 \%$ in groundwater has been detected by studying the groundwater data by CGWB. 
Air and temperature: 28\% of the land area shows an increase in Land Surface temperature in summer months derived from Moderate Resolution Imaging Spectrometer (MODIS). This is due to an increase in a built-up area and decreasing ground cover and the beginning of the urban heat island effect which impacts the thermal comfort and quality of life. A significant increase in Aerosol Optical Depth analysis has been observed with $92 \%$ area showing an increase in summer months and $91 \%$ area showing an increase in pre-monsoon months from 2009-19. This indicates a rise in air pollution in the deterioration of air quality which can be attributed to an increase in construction activities, decrease in vegetation cover, increase in air polluting industries.

\section{The state of Ecosystem for a transforming town-Malia Hatina}

An agrarian town near a Wildlife Sanctuary, the transforming town shows a decrease in farmland by $29 \%$ in 5 years from $2015-2019$. There is a significant increase in scrublands and wastelands by $24 \%$ and a reduction of water bodies by $46 \%$. This reflects the change in land use is underway due to its transitioning status. The town has yet not exhibited significant growth in its built-up land use.

Water: While the surface water bodies show a decrease for the region and the town, as seen through LULC analysis, the use of groundwater has increased which is evident from the fact that the region supports three crops in a year. The status of groundwater is safe i.e., indicates that there is a balance between recharge, draft, and natural discharge, and there is no significant decline in groundwater status in pre-monsoon or post-monsoon. This is possibly due to the enhanced precipitation observed over the years and the abundance of pervious surfaces. However, the fluoride content of groundwater has increased and violation of up to $100 \%$ was recorded in the total hardness of water is more than 50 $\%$ of the samples from the well have been found to exceed the limits of $200 \mathrm{mg} / \mathrm{L}$ set by IS 10500 . Environmental Clearance data granted in the recent past has led to new limestone industries near the Malia Hatina town. A Normalised Differential Turbidity Index of the river shows patches of the river with an increase in turbidity from 2016 to 2020, especially in stretches of the Meghal river passing from the town. Turbidity of surface water bodies increases due to biological growth (run-offs of nutrient-rich irrigation water into the river) or due to disposal of industrial and municipal wastewaters or due to a combination of agricultural run-offs, and effluent disposal.

\section{Conclusions and Discussions}

The level of urbanization defies the scale, type, and nature of anthropogenic activities which define the level of disbalance in the ecosystem. As the village transforms into a town and then a city and a megalopolis, the hotspots or critical issues impacting the status of the land, water, air, flora and fauna, and quality of life parameters.

Building resilience measures in urban settlements have been successful only when stakeholder awareness, participation have been ensured in the process of planning for the same ownership and accountability and only such responses can be sustainable which are built through stakeholder consultation and participation.

Policies with a strong emphasis on green initiatives in Development Control Regulations and Byelaws need to be adopted. Programs to improve green cover, protect water bodies, eco-projects to mitigate damages and restore the ecosystem, and plans to control emissions and pollutions are some ways in 
which these urbanized settlements can respond to the changes and impacts on ecosystems. Eco solutions are no-regret solutions that are not capital intensive yet provide sustainable impact.

Nature-based solutions provide a sustainable way of addressing multiple environmental and social and economic issues by resonating with nature and mimicking nature's curative and healing measures. Nature-based solutions can be integrated into policies, programs, projects, and plans and help in preserving the integrity of the ecosystem, manage ecosystems to meet human and livestock needs as well as restore degraded ecosystems. $\mathrm{NbS}$ can mainstream over design policies and measures while allowing ownership and participation of stakeholders.

Assessments are carried to bring out trends that are specific to the temporal and spatial scales of a region. The agility of the framework provides an opportunity for its application on settlements of different scales. Further, to which a roadmap can be created for engagement with cities, towns, and villages on data collection, assessments, and policies. Data management for cities and towns can be managed effectively.

Sub-national authorities at the state level are expected to play a key role in actively incorporating climate change considerations into day-to-day governance, adopting climate-friendly policies and programs, regulations, and investment decisions (Ministry of Environment, 2019). Therefore, State Action Plans on Climate Change (SAPCCs) would be a good starting point for this policy mainstreaming. SAPCCs formulated for the states, need to incorporate vulnerability assessments and climatic projections at local, regional, and state levels. There is a potential to align the ecosystem health assessment framework for evidence-based climate action plans. The sector-specific policies proposed in the action plan can be divided into urban, peri-urban, and rural areas. There is a scope to develop evidence-based projections and analysis for each sector in the action plans, to ensure contextualized solutions. For urbanized settlements like metropolis and megalopolis, the scope for precautionary measures is limited. Control measures and policies can limit further deterioration, while eco-sensitive mitigative and restorative measures can help in bringing back the balance between human habitation and the environment. In the case of peri-urban and smaller towns, the effective response for sustainable ecosystem management should focus on precautionary and protective measures to prevent the disbalance seen in urbanized settlements. Prioritizing actions and phasing them over a period provides an opportunity for optimal response at the right time despite financial,technical, and administrative limitations. Transforming town and villages provide an opportunity for preventive and protective responses to the emerging threats. This helps aid in agile urban management.

\section{References}

Bolund, P. A. (1999). Ecosystem Services in Urban Areas. Ecological Economics, 293-301. Retrieved from http://dx.doi.org/10.1016/S0921-8009(99)00013

Census, 2. (2011). Census of India 2011. Retrieved January 2021, from https://www.censusindia.gov.in/2011prov-results/paper2vol2/data_files/India2/1.\%20Data\%20Highlight.pdf

CGWB. (2019). India WRIS. Retrieved NOVEMBER 2019, from https://indiawris.gov.in/wris/\#/GWQuality CGWB. (n.d.). India WRIS. Retrieved NOVEMBER 2019, from https://indiawris.gov.in/wris/\#/GWQuality DISH, G. (2019). Directorate of Industrail Safety and Health. Retrieved 2019, from 
https://mahadish.in/registered_factories/index/9

Hualou Long, X. W. (2008). Analysis of Urban-Rural Land-Use Change during 1995-2006 and Its Policy Dimensional Driving Forces in Chongqing, China. Sensors, 8(2), 681-699. doi:10.3390/s8020681

Jari Niemelä, S.-R. S.-P. (2010). Using the ecosystem services approach for better planning and conservation of urban green spaces: a Finland case study. Biodiversity and Conservation, 19(11), 3225-3243. doi:10.1007/s10531-010-9888-8

Johnson, M. P. (2001). Environmental Impacts of Urban Sprawl: A Survey of the Literature and Proposed Research Agenda. Environment and Planning A: Economy and Space, 33(4), 717-735. doi:10.1068/a3327

K V Raju et al. (2018). Urban Environmental Governance in India. In P. o. Springer International Publishing AG, The Urban Book Series. Springer International Publishing AG.

Ministry of Environment, F. a. (2019). Towards evolution of a framework for the preparation of state level climate change strategy and action plan.

Nagendra H., S. H. (2013). Sub-regional Assessment of India: Effects of Urbanization on Land Use, Biodiversity and Ecosystem Services. In Urbanization, Biodiversity and Ecosystem Services: Challenges and Opportunities. Springer Dordrecht.

OECD. (2003). OECD Environmental Indicators Development measurement and use.

Ram, B. K. (1993). Remote sensing application in monitoring land-use changes in arid Rajasthan. International Journal of Remote Sensing, 3191-3200. doi:10.1080/01431169308904433

Rees, W. E. (1996). Urban ecological footprint: Why cities cannot be sustainable - And why they are a key to sustainability. Environmental Impact Assessment Review, 223-248.

Robert I. McDonald, P. J. (2013). Urbanization and Global Trends in Biodiversity and Ecosystem Services. In Urbanization, Biodiversity and Ecosystem Services: Challenges and Opportunities (pp. 31-52).

Sutton-Grier, A. E. (2019). Conservation of Wetlands and Other Coastal Ecosystems: a Commentary on their Value to Protect Biodiversity, Reduce Disaster Impacts, and Promote Human Health and Well-Being. Wetlands, 39(6), 1295-1302. doi:10.1007/s13157-018-1039-0

World Bank, 2. (2019). World Bank Development Indicators. Retrieved April 2021, from https://tradingeconomics.com/india/urban-population-percent-of-total-wb-data.html 